\title{
Khitobah Walimah Sebagai Model Tabligh
}

\author{
Erin Derostiani Hermawan ${ }^{1 *}$, Siti Sumijaty ${ }^{1}$, Aang Ridwan ${ }^{2}$ \\ ${ }^{1}$ Jurusan Komunikasi dan Penyiaran Islam, UIN Sunan Gunung Djati, Bandung \\ *Email : erinderostiani96@gmail.com
}

\begin{abstract}
ABSTRAK
Penelitian ini bertujuan untuk mengetahui Teknik Khitobah Ustadz Jumdia pada momentum Walimatul Aqiqah di kampung Cileunca Kab. Bandung Barat selanjutnya, untuk mengetahui Pendekatan Khitobah yang diterapkan Ustadz Jumdia pada momentum Walimatul Aqiqah di kampung Cileunca Kab. Bandung Barat dan yang terakhir untuk mengetahui Keterlibatan unsur-unsur Tabligh Ustadz Jumdia pada momentum Walimatul Aqiqah di kampung Cileunca Kab. Bandung Barat. Fokus penelitian yang akan dilakukan oleh penulis mengenai bagaimana Teknik Khitobah Ustadz Jumdia pada momentum Walimatul Aqiqah di kampung Cileunca Kab. Bandung Barat,Bagaimana Pendekatan Khitobah yang diterapkan Ustadz Jumdia pada momentum Walimatul Aqiqah di kampung Cileunca Kab. Bandung Barat,Bagaimana Keterlibatan unsur-unsur Tabligh Ustadz Jumdia pada momentum Walimatul Aqiqah di kampung Cileunca Kab. Bandung Barat. Metode penelitian yang digunakan adalah metode deskriptif. Metode deskriptif merupakan suatu metode dalam meneliti status sekelompok manusia, suatu objek, untuk melukiskan secara sistematis fakta atau karakteristik populasi tertentu atau bidang tertentu secara faktual dan cermat. Hasil penelitian ini menunjukan bahwa khitobah walimah sebagi model tabligh yang di lakukan oleh ustadz Jumdia pada momentum aqiqah yaitu sumbernya adalah Ustadz Jumdia pesannya tentang amar ma'ruf nahyi munkar berlombalomba dalam kebaikan serta mensyukuri nikmat Allah SWT, metode salurannya secara langsung tatap muka sasarannya ibu-ibu, bapak bapak. Remaja, media yang digunakan berupa mikrofon dan teks tertulis efeknya menambah wawasan ilmu pada mad'u perubahan sikap.
\end{abstract}

Kata Kunci : Khitobah; Walimah; Aqiqah

\section{ABSTRACT}

This study aims to find out the Khitobah Ustadz Jumdia Technique on the momentum of Walimatul Aqiqah in Cileunca Kab. West Bandung then, to find out the Khitobah Approach applied by Ustadz.Jumdia on the momentum of Walimatul Aqiqah in Cileunca Kab. West Bandung and the last to find out the involvement of the elements of Tabligh Ustad₹.Jumdia on the momentum of Walimatul Aqiqah in Cileunca Kab. West Bandung.

Tabligh: Jurnal Komunikasi dan Penyiaran Islam Volume 3 Nomor 4 (2018) 411-427

411 
E.D.Hermawan. S. Sumijaty. A.Ridwan

The focus of the research that will be carried out by the author about how the Khitobah Ustadz Jumdia Technique is on the momentum of Walimatul Aqiqah in Cileunca Kab. West Bandung, What is the Khitobah Approach applied by Ustadr. Jumdia on the momentum of Walimatul Aqiqah in Cileunca Kab. West Bandung, How is the involvement of Tabligh Ustadz. Jumdia elements in the momentum of Walimatul Aqiqah in Cileunca Kab. West Bandung. The method used is descriptive method. Descriptive method is a method of examining the status of a group of people, an object, to systematically describe the facts or characteristics of a particular population or a specific field in a factual and careful manner. The results of this study indicate that the khitobah walimah as a tabligh model performed by Ustadz.Jumdia on the aqiqah momentum is the source is Ustadz. Jumdia the message about amar ma'ruf nabyi munkar competing in goodness and grateful for the blessings of Allah SWT, the channel method directly face to face the target ladies and gentlemen. Teenagers, the media used in the form of microphones and written text the effect of adding knowledge to maduu change of attitude.

Keywords: Khitobah; Walimah; Aqiqah

\section{PENDAHULUAN}

Khitobah adalah ceramah atau pidato yang disampaikan oleh mubaligh kepada jamaah (mad'u) untuk menyampaikan ajaran-ajaran Islam melalui media lisan baik berupa ibadah mahdhoh ataupun yang tidak terkait dengan ibadah mahdhoh. Ustadz Jumdia merupakan mubaligh yang sudah terbiasa berdakwah menyampaikan ajaran-ajaran Islam kepada masyarakat yang menjadi sasaran dakwahnya. Kiprah beliau dalam bertabligh sudah tidak di ragukan lagi selain beliau menyampaikan ajaran Islam, beliau juga mampu menyelesaikan problematika umat, membimbing masayarakat setempat untuk lebih baik dan lebih mengenal Tuhannya. Beliau juga berhasil mendirikan memimpin dan membina anak-anak di Yayasan Riyadul Mubtadiin baik dari anak kecil, remaja, maupun dewasa hingga membina serta mengisi acara pengajian

Ustadz Jumdia ini dikenal sebagai Ustadz yang memiliki ciri khas dalam segi berbicara atau retotikanya, beliau menggunakan tekhnik khitobah yang khas dengan celetehan atau pengulangan kata yang sangat sering, beliaupun melakukan banyak kegiatan selain mengajar di Yayasannya juga menjadi salah satu staff di suatu instansi sekolah yang berada di Cileunca Kecamatan Cikalongwetan, Kegiatan yang dilakukan oleh Ustadz Jumdia untuk menarik masyarakat agar mau mendengarkan apa yang disampaikannya yaitu setiap satu bulan sekali berkumpul di masjid untuk berdoa bersama, tentu mereka juga butuh kegiatan rohani. Adapun kegiatan sosial yaitu khitanan masal, pembakian sembako, kalau datang Idul Adha kita bagikan potongan daging kurban. Kerjasama dengan karang taruna, dengan pemerintah setempat.

Keadaan masyarakat disana yaitu minim akan ilmu pengetahuan tentang agama khususnya pada kalangan remaja, pemuda-pemudi yang karena sibuk

Tabligh: Jurnal Komunikasi dan Penyiaran Islam Volume 3 Nomor 4 (2018) 411-427 
Khitobah Walimah Sebagai Model Tabligh, Tekhnik Khitobah Ustadz Jumdia pada Momentum Aqiqah dengan sekolah dan kerja di jalanan maksudnya rata-rata para pemudanya kerja menjadi supir truk besar atau sebagai kondektur. Maka dalam pengajian sering ditekankan dalam pemahaman keagamaan khususnya dalam berakhlakul karimah. Ustadz Jumdia ini sering d undang dalam walimah apapun baik itu tentang pernikahan. Khitanan maupun yang lainnya karena ustadz Jumdia ini satu-satunya ustadz yang terpakai dan terbiasa memimpin suatu acara maka dalam penelitian ini lebih di khususkan kedalam tekhnik khitobah ustadz Jumdia dalam momentum Walimah Aqiqah.

Momentum walimah aqiqah ini beliau berkutat dengan khasnya pembawaan retorika beliau yang membius semua da'i untuk memberikan wawasan lebih tentang agama khususnya dalam tata cara bagaimana aqiqah itu berlangsung dari awal hingga akhir acara serta bagaimana beliau memimpin dan menyampaikan maksudnya apa yang dimaksud dengan aqiqah. Aqiqah ini bertujuan untuk mengucap rasa syukur terhadap Allah SWT karena dengannya memberikan rezeki yang berlimpah berupa bayi yang baru lahir baik itu perempuan maupun laki-laki yang di berikan dalam suatu keluarga baru.

Peran Ustadz Jumdia yang tetap tangguh dan teguh pendirian untuk bertabligh, tetap berwibawa dan tak takut akan segala yang hambatan yang menghalanginya, beliau tetap mensyiarkan agama Islam karena itu kewajiban sebagai seorang muslim untuk mengajak dan mengingatkan pada hal yang benar dan berlandaskan Al-Qur'an dan As-Sunnah.

Realita yang sedemikian rupa menimbulkan rasa ke ingin tahuan penulis terhadap Bagaimana Teknik Khitobah Ustadz Jumdia pada momentum Walimatul Aqiqah di kampung Cileunca Kab. Bandung Barat?, Bagaimana Pendekatan Khitobah yang diterapkan Ustadz Jumdia pada momentum Walimatul Aqiqah di kampung Cileunca Kab. Bandung Barat?, dan Bagaimana Keterlibatan unsur-unsur Tabligh Ustadz Jumdia pada momentum Walimatul Aqiqah di kampung Cileunca Kab. Bandung Barat? maka penulis bermaksud melakukan penelitian dengan judul "Khitobah Walimah sebagai Model Tabligh" Teknik Khitobah Ustadz Jumadia pada Momentum Aqiqah di Cileunca Kabupaten Bandung Barat.

Penulis melakukan penelitian pada masyarakat, baik kepada remaja, ibuibu, maupun bapak-bapak di Kampung Cileunca Kabupaten Bandung Barat. Alasan penulis melakukan penelitian Itu merupakan tantangan bagi mubaligh bisa bertabligh menyampaikan ajaran-ajaran islam sehingga masyarakat disana sedikit-demi sedikit bisa memahaminy, dan lebih semangat lagi dalam menjalankan syariat Islam.

Metode penelitian yang digunakan dalam penelitian ini ada metode deskriptif. Dalam metode deskriptif, dapat diteliti masalah normatif bersamasama dengan masalah status dan sekaligus membuat perbandingan-perbandingan antarfenomena. Perspektif waktu yang dijangkau dalam penelitian deskriptif adalah waktu sekarang, atau sekurang-kurangnya masih jangka waktu dalam 
Dalam prakteknya peneliti terjun ke lapangan: gejala-gejala diamati, dikatagori, dicatat, dan sedapat mungkin menghindari pengaruh kehadirannya untuk menjaga keaslian gejala yang diamati (Jalaluddin Rakhmat, 1985: 34-35). Penelitian ini juga merupakan penelitian atau hipotesis yang berkaitan dengan awal proses kelahiran anak dari semasa dikandung sampai pada acar aqiqahan atau kegiatan pemberian nama sekaligus syukuran. Merupakan suatu fenomena yang sangat menarik seorang mubaligh yaitu Ustadz Jumdia bisa bertabligh menerapkan ajaran syariat Islam dalam kegiatan Walimatul Aqiqah, yang telah diketahui bahwa disana masih kekurangan Mubaligh dalam hal ini.

\section{LANDASAN TEORITIS}

Teori yang dijadikan landasan dalam penelitian ini adalah Teori Lasswel. Dalam pengertiannya, Islam merupakan agama universal yang mengatur seluruh tatanan kehidupan manusia yang berpacu pada Alkuran dan Assunnah. Islam juga mengatur seluruh tatanan kehidupan dalam berbagai aspek, seperti halnya dalam bentuk pengembangan Islam itu sendiri, contohnya dalam mengembangkan keagamaan melalui tradisi ataupun budaya. Islam memberikan seluruh tata aturan yang dapat memeberikan keleluasaan dalam mengembangkan aturan tersebut asal tetap ada dan tak keluar dari syariat Islam itu sendiri. Sistem yang dibawa oleh Islam sesungguhnya padat dengan nilai dan memberikan manfaat bagi manusia. Sistem Islam ini tidak hanya berguna bagi masyarakat Muslim saja melainkan untuk semua orang yang non muslim (masyarakat umumnya).

Khitobah adalah ceramah atau pidato yang disampaikan oleh mubaligh kepada jamaah (mad'u) untuk menyampaikan ajaran-ajaran Islam melalui media lisan baik berupa ibadah mahdhoh ataupun yang tidak terkait dengan ibadah mahdhoh. Khitobah itu sendiri secara leksikal berasal dari akar kata, khataba, yakbtubu, khutbatanatau khitobatan yang berati; berkhutbah, berpidato, meminang, melamar, bercakap-cakap, atau mengirim surat. Atas makna leksikon ini, Aliyudin mengutif terminologi khitobah yang dikemukakan oleh Harun Nasution dan Al-Jurjani (Aliyudin, 1995: 57).

Kelahiran seorang bayi dalam sebuah rumah tangga salah satu hal yang didambakan. Sepasang suami istri sangat merindukan datangnya momongan bayi mereka. Banyak pernikahan yang mengalami ketidak-harmonisan hanya karena tidak adanya bayi yang lahir dan diharapkan dapat melanjutkan cita-cita orangtua mereka. Ajaran Islam adalah ajaran yang sempurna dan mengajarkan agar sebuah keluarga mensyukuri nikmat lahirnya seorang bayi dengan pelaksanaan aqiqah yang telah dicontohkan oleh Rasulullah SAW. Masyarakat muslim pun telah menerima ajaran tersebut dengan senang hati dan lapang dada seraya ingin menunjukan ketundukkan merek kepada Allah SWT dan Rasu-Nya (Ahmad Bisyri, 2013: 99). 
Khitobah Walimah Sebagai Model Tabligh, Tekhnik Khitobah Ustadz Jumdia pada Momentum Aqiqah

Media tabligh adalah salah satu bentuk komunikasi, maka sebagaimana komunikasi yang juga memerlukan media, maka tabligh pun tidak terlepas dengan media dalam pelaksanaanya. Media adalah alat yang dijadikan penyampaian pesan tabligh yang lebih efisien dan efektif. Media dapat menembus ruang dan waktu. Media tabligh terdiri dari "media tradisional, media modern dan perpaduan dari media tradisional dan modern. Media yang sering kita gunakan dalam bertabligh jika dilihat dari perkembangannya bisa diklasifikasikan menjadi tiga bagian yaitu: Media tradisional, media modern dan perpaduan media tradisional dan media modern (Subandi, 1994: 89-92).

Metode itu sangat diperlukan oleh mubaligh dalam menyampaikan pesan tablighnya. Metode tabligh adalah cara yang dilakukan oleh Mubaligh untuk menyampaikan materi tabligh untuk mencapai tujuan tertentu. Umumnya metode tabligh merujuk pada surat An Nahl ayat 125. Dalam ayat ini metode tabligh ada tiga, yaitu: al-hikemah, mau'izah al-hasanah dan mujadalah billati hiya ahsan (Saputra, 2012: 246-253). Pada garis besarnya, bentuk Tabligh ada 2 yaitu: Tabligh Lisan (Khitabah) dan Tabligh Tulis (Kitabah). Berdasarkan kedua bentuk Tabligh tersebut, maka dapat diklasifikasikan sebagai berikut:

Pertama, metode ceramah. Metode ceramah merupakan yaitu cara menyampaikan materi ilmu pengetahuan dan agama kepada anak didik yang dilakukan secara lisan (Majid dan Zayadi 2005: 137). Penerapan metode ceramah dalam pendidikan Islam disinyalir dalil Al-Qur'an. Metode ini terilhami dari kisah Nabi Musa A.S ketika menyampaikan permohonan kepada Allah SWT. Firman Allah SWT dalam QS Thaha ayat 25-28

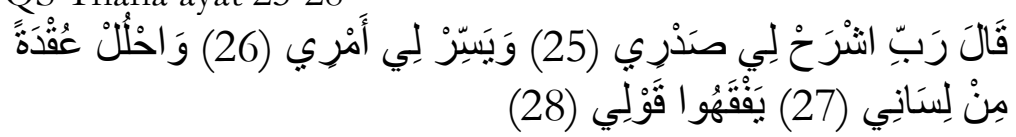

Dia (Musa) berkata, "Ya Tubanku, lapangkanlah dadaku, Dan mudabkanlah untukeu urusanku. Dan lepaskanlah kekakuan dari lidabku, agar mereka mengerti perkataanku" (Latnah Pentashihan Mushaf Al-Qur'an, 2007: 313).

Ayat ini yang menjelaskan bahwa dalam proses penyampaian materi melalui metode ceramah hendaknya disampaikan dengan jelas, logis (masuk akal), berbobot, dan faktual, sehingga pendengar cepat memahami, mengerti dan merima.

Kedua, metode diskusi. Metode diskusi merupakan salah satu cara mendidik yang berupaya untuk memecahkan masalah yang dihadapi, baik dua orang atau lebih yang masing-masing mengajukan argumentasinya untuk memperkuat pendapatnya. Untuk menggunakan metode ini hendaknya jangan menghilangkan perasaan obyektivitas dan emosionalitas yang dapat mengurangi bobot pikir dan pertimbangan akal yang semestinya (Majid dan Zayadi, 2005: 141).

Ketiga, metode bimbingan (konseling). Metode bimbingan atau konseling merupakan cara yang digunakan dalam proses bimbingan dan konseling dan yang terakhir metode pemberdayaan masyarakat.

Tabligh: Jurnal Komunikasi dan Penyiaran Islam Volume 3 Nomor 4 (2018) 411-427 
E.D.Hermawan. S. Sumijaty. A.Ridwan

Teori retorika berpusat pada pemikiran mengenai retorika, yang disebut Aristoteles sebagai alat persuasi yang tersedia. Artinya, pembicara harus bisa membujuk khalayaknya untuk mempertimbangkan tiga bukti retoris yakni logika (logos), emosi (pathos), dan etika/ kredibilitas (ethos). Aristoteles mendefinisikan retorika (rhetoric) adalah sebagai alat-alat persuasi yang tersedia. Asumsi yang dikemukakan oleh Aristoteles terdiri dari dua asumsi yakni sebagai berikut: Pertama, Pembicara yang efektif harus mempertimbangkan khalayak mereka. Kedua, Pembicara yang efektif menggunakan beberapa bukti dalam persentasi mereka.

Asumsi pertama menggarisbawahi bahwa dalam konteks public speaking, Aristoteles menyatakan bahwa hubungan antara pembicara dan khalayak harus dipertimbangkan. Para pembicara tidak boleh menyusun atau menyampaikan pidato mereka tanpa mempertimbangkan khalayaknya. Menganalisi khalayak (audienceanalysis), yang merupakan proses mengevaluasi khalayak dan latar belakngnya (seperti jenis kelamin, usia, tingkat pendidikan, tingkat ekonomi, sosial dan lain sebagainya). Dan menyusun pidato sedemikian rupa sehingga pendengar bisa memberikan respon sebagimana yang diharapkan oleh pembicara.

Asumsi kedua yang mendasari teori Aristoteles berkaitan dengan apa yang dilakukan pembicara dalam persiapan pidato mereka dan pembuatan pidato tersebut. Bukti-bukti yang ditunjukan Aristoteles merujuk pada cara-cara persuasi, yakni terdapat tiga bukti yaitu ethos, pathos, dan logos. Ethos merujuk pada karakter, intelegensi, dan niat baik yang dipersepsikan dari seorang pembicara ketika hal-hal itu ditunjukan melalui pidatonya. Logos adalah bukti yang digunakan oleh pembicara-argumen mereka, rasionalisasi, dan wacana. Bagi Aristoteles, logos mencakup penggunaan beberapa praktik termasuk menggunakan klaim logis dan bahasa yang jelas. Pathos berkaitan dengan emosi yang dimunculkan dari para pendengar. Aristoteles beragumen bahwa pendengar menjadi alat pembukti ketika emosi mereka digugah: para pendengar menilai dengan cara berbeda ketika mereka dipengaruhi oleh rasa bahagia, sakit, benci atau takut (West dan Lynn, 2008: 5-8).

Maudu merupakan materi atau ajaran Islam secara keseluruhan yaitu tuntuna Allah SW'T sebagi pedoman hidup meliputi 'Amar Ma'ruf Nabyi Munkar' bagi kehidupan manusia. Pesan tabligh dapat dijabarkan meliputi :

Pertama,Al-Qur'an, dalam hal ini mubaligh harus menguasai dan memahami ayat-ayat Al-Qur'an kedua, Hadits, dalam hal ini mubaligh harus benar memahami, dan memngetahui sejarah Rasulullah SAW, sehingga menjadi bahan atau strategi penyampaian dalam mensyiarkan agama Islam di masa kini. Ketiga, Rakyu Ulama, ulama sebagai warosatul anbiya perlu diketahui sejarah kehidupannya. Sebab, beliau juga sebagai mubaligh yang biasanya banyak melakukan penyebaran, penyiaran, dan penerangan Islam secara ikhlas dan 
Khitobah Walimah Sebagai Model Tabligh, Tekhnik Khitobah Ustadz Jumdia pada Momentum Aqiqah penuh keberanian (Asmuni Syakir, 1983: 63).

Penentuan pesan dalam kegatan pelaksanaan tabligh harus sesuai penjabaran dan pengelolaan kondisi mad'u. Dengan demikian mudah diterima dan dipahami oleh objek tabligh tersebut serta mudah terealisasikan dala kehidupan mad'u sehari-hari. Secara sederhana dapat diketahui pesan tabligh mencakup penjabaran dan pengolahan ajaran islam baik dalam wujud pengetahuan, nilai maupun sikap.

\section{HASIL DAN PEMBAHASAN}

Penulis melakukan penelitian kepada salah satu mubaligh di Kampung Cileunca beliau bernama Ustadz Jumdia beliau biasa dipanggil pak ustadz dan menjadi salah satu sesepuh di Kampung Cileunca. Beliau lahir di Bandung pada tanggal 13 Maret 1960 yang mana ayahnya juga seorang ustadz, beliau tinggal di Kampung Cileunca rt 04/rw 10 Desa Tenjolaut Kecamatan Cikalongwetan Kabupaten Bandung Barat.

Pada usia beliau menginjak 26 tahun beliau menikah dengan istri yang bernama Ustadzah Apong Nurhasanah kelahiran asli Purwakarta, pada tahun dan Alhamdulillah sudah dikaruniai tiga orang anak, yang pertama perempuan, kedua laki-laki dan yang ketiga juga laki-laki anak-anaknya sudah menikah kecuali si bontot yang masih mengemban ilmu di pesantren di Tasikmalaya, tak dapat dipungkiri bahwa keluarga ustadz Jumdia ini keturunan dari tokoh agama dan selalu mementingkan pendidikan serta memperdalam agama pada diri, keluarga dan anak-anaknya.

Beliau pernah mengenyam pendidikan formal hanya pada tingkat menengah pertama saja namun pada saat itu beliau sedang mengenyam di pendidikan pesantren memperdalam agama. Dan alhamdulillah seiringnya waktu pak ustadz meneruskan pendidikan formal sampai pada saatnya beliau ingin meneryuskan ke jenjang yang lebih tinggi yaitu perguruan tinggi yang berniat mengambil jurusan Pendidikan Agama Islam fakultas Tarbiyah di Jamisah kota Bandung.

Selama duduk di bangku sekolah beliau terkenal sebagai murid yang aktif terutama keaktifan beliau terlihat dalam bidang keagamaan. Sedangkan untuk pendidikan non formal beliau sempat mondok di pesantren Miftahul Huda hampir setiap hari beliau mengkaji kitab-kitab dan alhamdulillah banyak ilmu yang bisa beliau dapatkan. Bahkan sampai saat ini beliau dirumahnya berjejer banyak kitab-kitab dan buku tentang ketauhidan serta yang lainnya.

Dilihat dari status ekonominya bisa dikatakan beliau berasal dari keluarga yang berkecukupan, ayahnya mampu menyekolahkan beliau meskipun hanya sampai tingkat Sekolah Menengah Pertama tapi beliau mampu mengenyam pendidikan non formal di beberapa pesantren. Serta melihat dari sisi sosiologisnya ustadz Jumdia sosok yang sangta bertanggung Jawab terhadap anak 
E.D.Hermawan. S. Sumijaty. A.Ridwan

dan istri.

Beliau mendirikan yayasan di Kampung Cileunca ini yang bernama Royadul Mubtadiin, dan beliau adalah pemimpin yang amanah selain dari guru, sesepuh, panutan, beliau pun sangat dekat dengan masyarakat sekitar. Beliau aktif di organisasi-organisasi yang tak lepas dari keagamaan diantaranya Organisasi Da'i Kamtibnas dari Kapolres Cimahi, Organisasi FORSIMA (Forum Silaturahmi Imam Masjid) Kecamatan Cikalongwetan, organisasi FSGN (Forum Silaturahmi Guru Ngaji) sekabupaten Bandung Barat, organisasi FKDTA (Forum Komunikasi Diniyah Takmiliyah Awaliyah) alhamdulillah ini dalam pendidikan keagamaan se-Kabupaten Bandung Barat. Dan sampai saat ini beliau sangat haus akan penghargaan dan mengikuti beberapa kegiatan yang lainnya. Karena dari situlah motivasi-motivasi beliau untuk terus menjalankan syiar Islam.

\section{Teknik Khitobah Ustadz Jumdia pada momentum Walimatul Aqiqah}

Teknik khitobah Ustadz Jumdia ini dengan berlandaskan Amar Maruf Nabi Munkar, secara bil lisan, dan mauidatul khasanah. Dari beberapa macam walimah, Ustadz Jumdia berdakwah melalui momentum Aqiqah ini memiliki yang unik dan berbeda dari yang lain. Walimatul aqiqah yang dilaksanakan kadang mendadak tanpa mengabari ustadz terlebih dahulu kadang tinggal beberapa jam kedepan baru mengabari dan yang diterapkan oleh Ustadz Jumdia dalam melaksakan tugasnya yaitu berkhitobah, menggunakan teknik impromtu (spontan) dan naskah dalam membaca sholawat-sholawat yang akan di lantunkan bahkan kadang menggunakan teknik khitobah dengan cara menghafal (tanpa teks).

Teknik Impromptu itu sendiri merupakan membawakan sesuatu hal yang baik, ajaran Islam atau disebut juga dengan berkhitobah/berpidato tanpa persiapan apapun dan dituntut untuk mengisi suatu acara yang pembawaanya hanya mengandalkan pengalaman dan wawasan. Teknik Naskah dalam mambacakan beberapa sholawat ketika aqiqah berlangsung Ustadz Jumdia memiliki pembacaan yang sama namun dalam pembawaannya Ustadz Jumdia memiliki ciri tersendiri dan unik hanya dimiliki oleh beliau saja. Teknik naskah itu sendiri merupakan suatu tekhnik khitobah yang diterapkan Ustadz Jumdia yang menggunakan naskah dalam mensyiarkan atau berdakwah atau berpidato dan naskah tersebut telah dibuat serta di persiapakan sebelum acara walimatul aqiqah dilaksanakan.Selain dari dua teknik tersebut Ustadz Jumdia dalam pembawaannya menggunakan juga tekhnik khitobah menghafal yaitu teknik mensyiarkan dan berdakwah tanpa menggunakan teks, tekhnik ini yaitu menghafal suatu rencana yang akan dikomunikasikan kepada mad'u baik itu kepada keluarga yang bersangkutan maupun kepada masyarakat yang menghadiri walimatul aqiqah itu sendiri.

Diantara manfaat aqiqah, sebagaimana yang disebutkan oleh Ibnu Qayyim 
Khitobah Walimah Sebagai Model Tabligh, Tekhnik Khitobah Ustadz Jumdia pada Momentum Aqiqah Rahimahullah dalam kitabnya "tuhfatul Maudud" adalah Merupakan ibadah kepada Allah Swt, Merupakan sifat mulia untuk menghilangkan kekikiran, Memberikan makan kepada orang lain dan ini termasuk ibadah, Melepaskan gadaian si anak, agar ia bisa memberikan atau mendapatkan syafaat bagi orangtua, Menanamkan sunnah-sunnah yang disyari'atkan dan memberantas khurafat kejahiliyahan. Dengan adanya kebermanfaatan ini maka alhamdulillah di kampung Cileunca Kabupaten Bandung Barat masih kental dengan tradisinya sendiri yang dapat sejalan dengan sejalan dengan syariat Islam namun dalam kendala mengumpulkan pemuda-pemudi yang tidak sekolah yang hanya bekerja di jalanan seperti supir truk terlalu susah mengatur jadwal untuk pertemuan dalam pengajian bahkan dalam mengikuti momentum-momentum yang lainnya khususnya dalam momentum aqiqah.

Salah satu tujuan untuk bertabligh dan isi pesan tabligh ini yaitu jalan untuk membahagiakan atau mensejahterakan umat. Landasannya yaitu Q.S. AlAnbiya: 107”

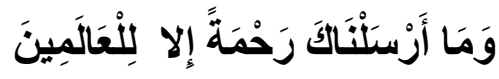

"Dan kami tidak mengutus engkau Muhammad melainkan untuk menjadi rahmat bagi seluruh alam"(Latnah Pentashihan Mushaf Al-Qur'an, 2007: 337).”

Maksud dan tujuan beliau dalam pembahasan serta pendekatan beliau dalam bertabligh yaitu untuk mensejahterakan umat - umat Nabi Muhammad SAW beliau tidak memandang bulu dan tidak membeda-bedakan atau fanatik dalam satu hal saja namun menyeluruh, universal, teratur dan tetap dalam jalanNya berlandaskan apa yang di perintah Allah.

Isi pesan tabligh atau cara berkhitobahnya ustadz Jumdia ini memiliki model dan teknik yang mempunyai ciri khas dan memiliki kejenakaan serta khas dalam membwa benda atau barang ketika bertabligh yaitu sapu tangan putih yang memiliki kekhasan wanginya. Isi pesan yang terkandung dalam walimatul aqiqah ini membahas tentang bagaimana rasa syukur terpanjat dan bagaimana tata cara dalam pelaksanaan aqiqah dengan adanya penyebelihan hewan dan kegiatankegiatan lainnya yang bertepatan dengan adat di Cileunca yang biasa dilaksanakan namun tidak keluar dari ajaran agama.

Ustadz Jumdia sangat energik, semangat nya masih berkobar dalam memimpin suatu acara walau usia nya sudah terbilang tua. Dan beliau memimpin suatu yayasan yang bernama Riyadul Mubtadiin dengan seperti itu baeliau mengedepankan pendidikan keagamaan tidak hanya di keluarganya namun mengajak masyarakat yang lain unutk terjun langsung pada hal baik dan memperdalam ilmu agamanya.

Isi pembahasan ini mengajak dan menerapkan sikap yang berlandaskan akidah serta menggunakan model yang mempengaruhi psikologi dan komuniksi ke segala arah seoerti pada model Menurut Mulyana (2003:132-160) Komunikasi 
E.D.Hermawan. S. Sumijaty. A.Ridwan

bersifat dinamis, sebenarnya komunikasi telah dibuat oleh para pakar, dan dari ratusan model yang paling popular diantaranya model komunikasi seperti berikut

Model S-R merupakan model komunikasi paling dasar. Model ini dipengaruhi oleh disiplin psikologi, khususnya yang beraliran behavioristik. Model tersebut menggambarkan stimulus-respons. Model inimenunjukkan komunikasi sebagai aksi-reaksi yang sederhana.

Model ini mempunyai keterkaitan sehingga menimbulkan aksi dan reaksi baik dari mubaligh dan madu nya sehinggu maudunya tersmpaikan dengan jelas dan dapat langsung di aplikasikan dengan tindakan. Selain dari model S-R ini dalam penyampaian dan isi pesan tabligh beliau sangat lah empiris dan masuk di akal. Teknik khitobah ini beliau gunakan agar terjalinnya jiwa sosisal yang tinggi dan pesan yang diberikan komunikator kepada komunikan terealisasikan dengan baik.

\section{Pendekatan Khitobah yang diterapkan Ustadz Jumdia pada momentum Walimatul Aqiqah}

Indikator pemahaman keagamaan itu bisa dilihat dari peningkatan keimanan masyarakat, perubahan akhlak, sikap mereka yang bisa saling toleransi antar perbedaan keyakinan dan juga bisa menegakan keadilan dalam kehidupan seharihari.

Disimpulkan bahwa pemahaman keagamaan adalah kemampuan untuk menafsirkan, menerjemahkan dan mengesploitasi ajaran-ajaran keagamaan (pengetahuan agama) yang dimiliki seseorang untuk disampaikan menggunakan kata-kata sendiri yang lebih sistematis dan mudah dimengerti oleh orang lain. Dengan adanya berbagai macam pendekatan khitobah menurut Bu Teti harus disesuaikan dengan kondisi masyarakat yang lebih kena ke inti yaitu melalui sikap bagamana pembawaan dan ke khasan seseorang dalam berkhitobah itu sendiri seperti apa yang telah penulis tanyakan kepada beliau pada saat itu, jawaban ibu Teti Suharti harus adanya pemahaman keagamaan terlebih dahulu.

'Pemahaman berasal dari kata paham artinya mengerti. Pemahaman keagamaan yaitu pengetahun yang telah dimiliki seseorang atau jamah yang ia dapatkan dari hasil menyimak terhadap apa yang ia dengarkan dari penyampaian mubaligh. Pemahaman orang itu berbeda-beda tergantung kepiawaian ia menyimak' (Senin,21 Mei 2018).

Pendekatan khitobah ustadz Jumdia kepada masyarakat di Kampung Cileunca dengan berbagai cara khususnya di prilaku dan sikap serta dalam kajian rutinan baik itu ibu-ibu khusus maupun di campur dengan bapak-bapak. Pendekatan lancar namun masih saja ada kendala lain jika ustadz Jumdia mencoba untuk mendekati pemuda pemudi yang agak susah diajak dan rata-rata mereka yang sudah bekerja dan menikah muda atau nakal pada saat remajanya. Kendala yang dialami Ustadz Jumdia ini memilik tantangan tersendiri sehingga 
Khitobah Walimah Sebagai Model Tabligh, Tekhnik Khitobah Ustadz Jumdia pada Momentum Aqiqah ketika dalam pengajian yang mengundang turun langsung yaitu beliau dan tak mudah menghadapi sikap mereka yang sangat liar, mungkin karena mereka tidak sering di Kampung Cileunca banyaknya di perjalanan karena rata-rata pemudapemudi yang tidak meneruskan sekolah ke jenjang yang lebih tinggi mereka sudah bekerja dan rata-rata menjadi supi truk atau kondektur truk.

Dalam teknik ini banyak media yang beliau gunakan tidak hanya mikrofon ataupun barang yang lainnya akan tetapi tekhusus dalam kegiatan Aqiqah beliau menggunakan banyak barang yang yang mengandung arti pesan yang baik namun tidak menyeleweng dari syariat Islam. Berbicara tentang khitobah, pengertian khitobah itu sendiri menurut Ibu Teti dalam wawancara memaparkan bahwa khitobah adalah suatu teknik yang didasarkan dalam kemampuan berbicara atau mengajak khalayak atau jamaah dengan isi pesan dakwah dan berdasarkan sumber yaitu Al-Quran dan As-Sunnah. Menurut ibu Teti bahwa ada perbedaan antara khitobah Diniyah dengan khitobah Tatsyiriyah.

Metode adalah cara yang dilakukan oleh seorang Mubaligh untuk mencapai suatu tujuan tertentu atas dasar hikmah dan kasih sayang serta ketulusan, dengan kata lain pendekatan Khitobah haruslah tertumpu pada suatu pandangan hukum oriented menempatkan pengharagaan yang mulia atas diri manusia (Toto Tasmara, 1994: 43).

Metode yang sangat penting harus di perhatikan, karena dengan menggunakan metode ini dimaksudkan agar mubaligh atau pelaksana khitobah mampu melaksanakan pendekatan yang tepat dan efektif dalam menghadapi suatu golongan tertentu. Penguasaan terhadap metode Khitobah ini merupakan faktor fundamental dalam menunjang keberhasilan khitobah.

Dalam penyampaian materi beliau selalu mempersiapakan diri dengan menyiapakan teks jika undngan nya sudah di beritahu dari awal dan terkadang secara impromtu secara mendadak dalam memeberikan materi karena momentum yang sangat mendadak namun beliau masih bisa meminimalisir dan tak pernah mengecewakan mad'u nya. Dalam penerapan tekhnik khitobah etika acara berlangsung dan jika di tinjau dari analisi yang berkaitan dengan model tablig pada momentum walimatul aqiqah ini terkait dengan model.

Model tanya jawab ini yaitu memberi kesempatan kepada masyarakat yang lain untuk bertanya kepada Ustadz Jumdia untuk dijawab dan dibahas. Model tanya jawab ini diharapakn mampu mengembangkan aspek kognitif serta daya nalar sehingga materi yang disampaikan akan lebih diserap dan lebih dapat diterima daripada model monolog. Akan tetapi terkadang dengan model ini banyak mengalami hambatan di antaranya kurang terfokusnya materi karena terkadang mad'u memberikan pertanyaan di luar materi yang disampaikan tersebut menjadi buyar dan tak terarah.

Model teladan adalah model figuritas atau keteladanan yang baik sehingga orang tertarik dengan materi-materi yang disampaikan tidak hanya menerima tetapi melaksanakan pesan dari materi tersebut. Model ini dilakukan dalam 
E.D.Hermawan. S. Sumijaty. A.Ridwan

penyampaian materi dakwah dengan jalan memberikan teladan langsung terhadap ibu-ibu sehingga ibu-ibu mearsa tertarik untuk mengikuti apa yang diserukan dalam materi tersebut. Model ini menitik beratkan kepada psikologis dengan membrikan contoh yang baik.

\section{Keterlibatan unsur-unsur Tabligh Ustadz Jumdia pada momentum Walimatul Aqiqah}

Unsur-unsur tabligh seperti materi, metode, pembawaan beliau itu sangat terealisasikan bahkan beliau sering melakukan aktivitas-aktivitas yang dapat menumbuhkan rasa simpati masyarakat setempat yang secara tidak langsung bisa mengajak mereka seperti halnya peradaban dan berprilaku yang Islami agar nantinya mereka bahkan kita bisa hidup aman, nyaman dan tentram.

Hal-hal yang sangat diperhatikan oleh Ustadz Jumdia pada saat melakukan tabligh yaitu tentu harus memperhatikan sunnah-sunnah Nabi artinya melihat kepada lingkugan disini. Kegiatan yang dilakukan Ustadz Jumdia dalam menarik perhatian masyarakat sekitar dalam mendengarkan tabligh beliau yaitu dengan berkumpul di masjid abik hanya sekedar Do'a bersama, atau pada saat bulan puasa selalu dengan buka bersama atau juga berkumpul seusai tarawih untuk tadarus bersama karena tentunya merekapun perlu kegiatan rohani. Adanya keterlibatan unsur-unsur yang ada dalam tabligh, beliau pun sebagai mubaligh sekaligus narasumber atau pembicara atau Da'i yang menjadi panutan masyarakat baik di kampung Cileunca maupun luar.

Kepribadian yang dimiliki ustadz Jumdia atau sebagai mubaligh pun harus memiliki standar Kepribadian mubaligh itu sendiri ada yang bersifat ruhaniah dan jasmaniah. Kepibadian yang harus dimiliki mubaligh secara ruhaniah : iman dan takwa kepada Allah SW'T, ikhlas dan tidak mementingkan diri sendiri, ramah, tawadhu, jujur, tidak memiliki sifat egois, sifat terbuka dan tisak memiliki penyakit hati.Selain menjadi mubaligh yang menjadi mad'u atau mubalagh yang sering disebut dengan pendengar atau jamaah atau komunikan ustadz Jumdia ini tidak hanya di kampung Cileunca saja namun kadang kala ada undangan dari luar dan memiliki pekerjaan atau kegiatan lain selain berceramah. Mad'u atau lebih familiar sebut saja mubalagh di kampung Cileunca ini tidak mematokkan pada kaum pria saja namun pada masyarakat umum baik anak-anak, remaja, pemudapemudi, ibu-ibu, dan bapak-bapak. Unsur tabligh yang di emban yaitu yang ketiga adalah maudu atau sering disebut dengan pesan tabligh, pesan tabligh dalam hal ini khususnya aqiqah sangat mengisyaratkan pesan-pesan atau rasa syukur telah lahirnya seorang bayi kedunia dengan rasa syukur dan bangga yang di panjatkan pada Allah SWT atas rezekinya, ustadz Jumdia memberikan pesan atau nilai ke islaman kepada keluarganya khususnya orangtua bayi yang baru melahirkan, pesan tabligh pun bisa berupa hal atau kegiatan umum bik dalam ceramah harian dan mingguan di suatu majelis. 
Khitobah Walimah Sebagai Model Tabligh, Tekhnik Khitobah Ustadz Jumdia pada Momentum Aqiqah

Materi yang disampaikan tidak hanya seputar momentum aqiqah saja numun banyak unsur dan pesan yang disampaikan dan apapun itu yang berkaitan dengan nilai-nilai keIslaman, materi yang di sampaikan beliu ini bersifat umum dan pastinya berlandaskan as sunnah dan al quran yang dapat menjadi avuan hidupnya dan dasar penguatan dalm pembicaraannya seperti dlam wawancara tanya jawab bersama bapak Yayan yang saya temui menurut beliau pun sama tidak hanya materi aqiqah saja namun bersifat umum.

Materi yang disampaikan oleh Ustadz Jumdia kepada masyarakat ada beberapa macam diantaranya seputar, "pertama akidah itu mengenai tauhid, rukun iman, kebenaran atau wahyu dan hubungan manusia dengan Allah. kedua fiqih atau syariah membahas mengenai bab Shalat, bab Puasa, Haji yang termasuk ke dalam Rukun Islam, muamalah, hal-hal yang mengatur hubungan manusia dengan manusia seperti hukum pernikahan, waris, aqiqah, dagang dan lainnya. Ketiga akhlak membahas mengenai tingkah laku, tatakrama atau budi pekerti, tabiat, nilai-nilai apakah itu nilai yang baik atau yang buruk" Yayan selaku DKM. Keterlibatan unsur yang keempat yaitu Ushlub atau sering disebut juga dengan Metode Tabligh, metode tabligh disini yaitu pembawaan ceramah untuk menyampaikan isi pesan tabligh yang di bawa oleh ustadz Jumdia kepada khalayak dengan caranya sendiri yaitu selalu menyelipkan pesan-pesan keislaman dengan cara atau contoh modern yang ada dan menyesuaikan mad'u yang sedang didepannya. Sedangkan metode tabligh adalah cara-cara tertentu yang dilakukan oleh seorang mubaligh kepada mubalagh untuk mencapai suatu tujuan atas dasar hikmah dan kasih sayang. Telah dijelaskan sebelumnya dalam unsur-unsur tabligh bahwa Tanpa metode tabligh, bisa jadi pesan dakwah yang akan disampaikan akan lnih monoton dan kurang kena. Oleh karena itu, metode sangat penting peranannya dalam kegiatan tabligh agar pesan yang disampaikan mubaligh sampai kepada muballagh dan mengena.

Dari pengertian Metode tabligh di atas, dapat disimpulakan bahwa, metode tabligh bagi seorang mubaligh memang sangat penting. Selain metode, adapun media dalam penyampaian ustadz jumdia dalam bertabligh yaitu menggunakan media microfon, suatu isyarat benda maupun yang lainnya. Selain dari benda tersebut media ustadz jumdia biasa menggunakan teks-teks tertulis sebagai bantuan dalam melaksanakan keberlangsungan dakwahnya, media tabligh itu sendiri merupakan sesuatu yang dijadikan penyalur atau jembatan atau bantuan untuk keberlangsungan bertabligh (menyampaikan syariat-syariat Islam).

Jika dianalisis lagi dari sisi Model Harold Lasswel, maka konsep metode tabligh Ustadz Jumdia yaitu :

Pertama, Who (siapa/sumber), Who dapat diartikan sebagai sumber atau komunikator. Di dalam tabligh itu disebut mubaligh atau da'i. Mubaligh atau da'i adalah pelaku utama atau pihak yang mempunyai kebutuhan untuk berkomunikasi dan yang memulai suatu komunikasi, baik itu seorang individu, kelompok, organisasi, maupun suatu negara sebagai komunikator. Dalam Tabligh: Jurnal Komunikasi dan Penyiaran Islam Volume 3 Nomor 4 (2018) 411-427 
E.D.Hermawan. S. Sumijaty. A.Ridwan

pengajian Majlis Ta'lim Ibu-ibu di Masjid Baetut Taqwa dan di dalam forum pengajian pemuda- pemudi di Yayasan Riyadul Mubtadiin dengan pembicaranya beliau sendiri yaitu Ustadz Jumdia. Selain itu beliau selalu mengahadiri momentum-momentum seperti PHBI, khususnya pada momentum aqiqah.

Kedua, Says what (pesan), Says menjelaskan apa yang akan disampaikan atau dikomunikasikan. Di dalam tabligh itu disbut dengan maudhu at-tabligh, yaitu pesan atau materi kepada komunikan (penerima), dari komunikator (sumber), atau isi informasi. Pesan merupakan seperangkat simbol verbal/non verbal yang mewakil perasaan, nilai, gagasan/maksud sumber tadi. Ada tiga komponen pesan yaitu makna, simbol untuk menyampaikan makna, dan bentuk/organisasi pesan. Dalam pengajian Majlis Ta'lim baik Ibu-ibu, bapak-bapak, remaja maupun campuran atau bahkan mad'u dari luar kampung Jadi, materi yang disampaikan tidak pilih-pilih tema tapi berurutan dari mulai QS. Al-Baqarah dan seterusnya. Ibu-ibu belajar tajwid dari sisi tahsin, belajar menerjmahkan dari sisi tarjamah, belajar mengkaji maknanya dari sisi tafsirnya, dan mengkaitkan dengan kehidupan sehari-hari agar mudah diaplikasikan dari sisi. Teknik khitobah yang diterapkan dalam momentum aqiqah ini berkenaan dengan bagaimana beliau membawa suatu barang atau dari keluarga nya itu sendiri yang menjadi khas atau simbolik dalam slametan bayi.

Ketiga,In Which Channel (saluran/media), Saluran/media adalah suatu alat untuk menyampaikan pesan dari komunikator (sumber) kepada komunikan (penerima) baik secara langsung (tatap muka) maupun tidak langsung (melalui media cetak atau elektronik). Walimatul aqiqah ini adalah suatu momen yang secara universal tidak semua melaksakannya namun makna yang terkandung dalam aqiqah hanya untuk mengucap syukur serta memeberikan harapan baik bagi keluarga dan bayi yang baru lahir untuk keberlangsungan hidup di masa depan dengan Do'a yang berlimpah yang bermula dari nama bayi agar tumbuh menjadi anak yang sholeh maupun sholehah.Dalam pengajian Majlis Ta'lim Ibuibu di Pondok Pesantren Tahfizh Miftahul Khoir In Which nya (media) nya adalah mimbar, kursi, meja, papan tulis, dan kadang memakai proyektor, mikrofon, kertas berisi tulisan dan LCD. Tempatnya kadang di Masjid atau di kelas. Jika di kelas maka anak remaja belajar dengan cara duduk di suatu karpet dengan disuguhi oleh jejeran bangku yang panjang di depannya.

Keempat,To whom (kepada siapa/penerima), Seseorang yang menerima informasi, bisa berupa suatu kelompok, individu, organisasi, atau suatu negara yang mnerima pesan dari sumber. Hal tersebut dapat disebut tujuan (destination), pendengar (listener), khalayak (audience), komunikan, penafsir, penyandi balik (decoder). Dalam pengajian maupun kumpulan biasa dengan Majlis Ta'lim Ibu-ibu di Yayasan Riyadul Mubtadiin khususnya untuk para remaja dan bapak-bapak jika ibu-ibu di masjid Jami Baetut Taqwa to whomnya adalah ibu-ibu, bapak-bapak, remaja. Ibu-ibu yang berjummlah kisaran 30 an 
Khitobah Walimah Sebagai Model Tabligh, Tekhnik Khitobah Ustadz Jumdia pada Momentum Aqiqah orang lebih. Usianya juga kisaran umur 35 tahunan ke atas sampai 50 tahunan. Rata-rata adalah Ibu Rumah Tangga yang ingin mengisi waktu dengan menuntut ilmu. Serta bapak-bapak yang berumur 38 tahun keatas yang pengangguran maupun bekerja karena kegiatan pengajiannya di laksanakan pada hari minggu saja itupun sore ba'da Ashar. Selain dari pengajian khusunya dalam berteknik khitobah yang mengahdiri momentum aqiqah ini beliau selalu di sambut dengan ramah oleh masyarakat yang dominan ibu-ibu dan bapak-bapak.

Kelima,With what effect (dampak/efek), Dampak atau efek yang terjadi pada komunikan (penerima) setelah menerima pesan dari sumber, seperti berubahnya sikap dan bertambahnya pengetahuan. Seperti yang telah di telaah dan dilihat langsung kelapangan dengan melalui wawancara ternyata ada perubahan sikap serta pengetahuan wawasan yang bertambah dan berubah ke arah yang lebih baik serta masyarakat di Kampung Cileunca itu semakin lebih baik dan terarah kepada hal-hal positif. Dampak dari walimatul aqiqah itu sendiri membuat masyarakatnya tidak hidup masing-masing melainkan saling berlomba-lomba dalam kebaikan bahkan lebih menerapkan Amar Ma'ruf Nahi Munkar pada sesama.

Teknik khitobah dalam momentum aqiqah yang digunakan ustadz Jumdia di ampung Cileunca ini denganberbagai teknik diantaranya menggunakan teks maupun tanpa teks biasa langsung ataupun memperispakan terlebih dahulu materi apa yang akan disampaikan. Namun dalam penyampaiaanya tidak hanya dalam aqiqah saja beliau selalu mnyelipkan apa- apa yang sejlalan dan baik untuk di ajarkan dan di beri tahukan. Dengan adanya Teknik khitobahbyang terstruktur dan sejalan maka dalam menyampaikan tabligh atau pesan ke Islaman dapat mudah di terima dengan lapang oleh jmaah atau mad'unya, karena ke khasan Ustadz Jumdia itu sendiri.

Penyampaian yang disampaikan ustadz Jumdia dalam berkhitobah dengan cara yang tegas namun ada selipan candaan untuk tetap paham dan tidak terlalu jenuh, teknik khitobah ustadz jumdia ini memiliki peranan yang sangat penting karena dalam penyampaiannya disitulah awal bagaimana membuat jamaah untuk cepat mengerti atau paham akan isi materi atau pesan dakwah yang disampaikan. Dengan adanya penelitian tentang aqiqah ini memudahkan bagi saya untuk menganalisis bagaimana teknik khitobah yang selama ini dilaksanakan di Kampung Cileunca dalam momentum aqiqah lebih mendalam sehingga memudahkan dan dapat dengan mudah mendapatkan informasi apa yang di inginkan sekaligus dekat dengan beliau Ustadz Jumdia. Di dalam penyampaiannya pun tidak terlalu kaku namun ada selingan kejenakaan agar mad'u atau pendengar tidak merasakan kejenuhan dan tetap fokus karena masa dimana ke fokusan seseorang hanya kurang lebih 30 menit jadi beliau dalam bertabligh pasti menyelipkan hal-hal atau obrolan yang membuat tertawa dengan memberikan contoh yang mengikuti zaman. 


\section{PENUTUP}

Sebagai akhir dari pembahasan dalam jurnal ini, maka dapat ditarik kesimpulan bahwa Model tabligh dalam penelitian ini yaitu Ustadz Jumdia, pesan tabligh nya untuk mensejahterakan dan mengajak masyarakat pada kebaikan serta dapat meningkatkan rasa syukur atas kelahiran seorang anak baik laki-laki mapun perempuan dengan panjatan sholawat serta doa kepada Nabi dan Allah SWT, saluran maupun media yang di gunakan dalam momentum aqiqah ini yaitu secara tatap muka atau langsung baik dengan persiapan maupun dengan dadakan impromptu tanpa teks, penerima atau jamaah atau mad'u yaitu ibu-ibu, bapakbapak, remaja, dan pemuda-pemudi, respon yang di dapat dari jamaah yaitu dapat meningkatnya wawasan serta pengetahuan khalayak dalam pemahaman keagamaan dan sikap sosialisasinya semakin erat.

Pertama, Teknik khitobah yang digunakannya yaitu dengan cara pendekatan secara emosional dan sosialisasi dengan masyarakat melalui pengajian beliau tidak hanya berfokus pada momentum aqiqah saja namun pada hal yang lain. Teknik khitobah beliau tidak hanya di depan mimbar saja namun bisa berupa tulisan yang dimuat di media cetak.

Kedua, Susunan acara dalam momentum aqiqah yaitu adanya peneyembelihan hewan yang bertepatan dengan segala penamaan nama bayi dan pemotongan rambut yang dilaksanakan secara bergantian oleh sanak keluarga dengan dipimpin doa oleh Ustadz Jumdia. Pendekatan ustadz Jumdia di kampung Cileunca dalam momentum walimatul aqiqah ini dengan cara bersosialisasi dan pengajian baik itu mad'u yang ibu-ibu, bapak, bapak, maupun remaja dan pemuda pemudi.

Ketiga, Keterlibatan unsur- unsur tabligh disini yaitu yang sebagai sumber dan mubalighnya itu sendiri adalah Ustadz Jumdia yang menjadi sasarannya atau jamaah atau mad'unya yaitu bapak-bapak, ibu-ibu, bapak-bapak, pemuda pemudi, remaja baik didalam lingkungan itu maupun luar kampung Cileunca, pesan yang disampaikannya yaitu umum dan tidak terikat oleh momentum aqiqah saja namun banyak hal lain yang beiau sampaikan. Dalam penyampaiannya beliau menyelipkan candaan agar tidak terjadinya kejenuhan pada mad'u dan tetap konsentrasi dalam mencari dan menggali ilmu yang berlandaskan al-qur'an dan As-sunnah ini.

\section{DAFTAR PUSTAKA}

Aliyudin, (2009). Dasar-dasar Ilmu Dakwah. Bandung: Widya Pdjadjaran.

Rakhmat, J. (2014). Retorika Modern Pendekatan Praktis. Bandung: PT Remaja Rosdakarya.

Saputa, W. (2012). Pengantar Ilmu Dakwah. Jakarta: PT RajaGrafindo Persada.

Subandi, A. (1994). Ilmu Dakwah Pengantar ke Arah Metodologi. Bandung: Syahida. 
Khitobah Walimah Sebagai Model Tabligh, Tekhnik Khitobah Ustadz Jumdia pada Momentum Aqiqah Syarifuddin, A. Hukum Perkawinan Islam Di Indonesia Antara Fiqh Munakahat Dan Undang-Undang Perkawinan, (Jakarta: Prenada Media, 2006), hlm. 155.

Abidin, S. (1999). Fiqib Munakahat I. Bandung. CV pustaka Setia.

Kusnawan, A. (2004). Komunikasi Penyiaran Islam. Benang Merah Press.

Sukayat, T. (2009). Quantum Dakwah. Jakarta: Rineka Cipta.

West, R., \& Lynn, H. T. (penerjemah Maria Natalia Damayanti). (2008). Teori Komunikasi. Jakarta: Salemba Humanika. 